\title{
EL MONASTERIO DE VALBUENA DE DUERO (VALLADOLID): LA DECORACIÓN MANIERISTA DE SU CLAUSTRO BAJO *
}

\author{
POR \\ MANUEL ARIAS MARTÍNEZ \\ Museo Nacional de Escultura
}

\begin{abstract}
The cistercian monastery located in Valbuena de Duero, Valladolid, boats well-preserved wall painting remains in the lower cloister. A number of Jesus Christ passion scenes situated by the vault omamentation, suggest the existence of an outstanding group of artists settled in Valladolid by the late xvith century and connected to the royal entourage and the Italian fashion.
\end{abstract}

Abordar una reflexión sobre la decoración mural del claustro bajo del monasterio de Santa María de Valbuena ha sido, desde la modestia de un trabajo de aproximación, una tarea agradable en la que la importancia arquitectónica del edificio, su monumentalidad y la belleza de sus volúmenes contrastan con una secular desidia en su conservación que inexorablemente lo conduce a la ruina.

Los frescos del claustro, vergonzosamente maltrechos, suponen una originalidad en el panorama de la pintura mural castellana tanto por su localización como por su tratamiento. Desde el comienzo nos sentimos en la necesidad de reivindicar una atención cuidadosa hacia un patrimonio que se pierde.

Esa intención de dar a conocer la existencia de un rico y variado repertorio ornamental se une al planteamiento de una posible hipótesis sobre la autoría de los trabajos. La presencia de artistas italianos en Valladolid y de la llegada temprana de influencias a un centro de gran pujan$\mathrm{za}$, ha sugerido nombres y corrientes en un panorama que merece un estudio globalizador del periodo, más reposado.

El monasterio de Valbuena. La decoración mural

Monasterio cisterciense en el valle, junto al río, entre Valbuena de Duero y Quintanilla de Arriba, delicioso paraje, antes fresco y frondoso, que va tornándose en árido y seco, gracias a la tala de mon-

\footnotetext{
* Este trabajo fue leído en el Simposio Internacional sobre el Arte en las abadías del Císter, entre los siglos xVI y XviII, celebrado en Alcobaça (Portugal), en septiembre de 1994.
} 
tes y sotos. Esta era la poética descripción con que iniciaba Francisco Antón el estudio que publicara en el año 1922 en el Boletín de la Sociedad Española de Excursiones y que formaba parte de una larga e interesante serie que dedicaría a los monasterios vallisoletanos ${ }^{1}$. La situación del monasterio en el valle del Duero lo disponía en una soledad privilegiada que iba a colaborar en el desarrollo de su fábrica y de su propia influencia dentro de la Orden.

Respondiendo al establecido plan cisterciense, el claustro se convierte en el eje que articula todas las dependencias monásticas. El claustro bajo, el que aquí nos interesa, está formado por cuatro crujías de ocho tramos cada una, cubierto cada tramo con bóveda de crucería y agrupando tres arcos de medio punto, realizado según la opinión de Antón en los finales del primer cuarto del siglo xiII. En los comienzos del siglo XVI se añadiría un espléndido claustro alto, como consecuencia de una ampliación espacial y de una adecuación a las nuevas modas, dentro de los parámetros ornamentales que marcaba el Renacimiento ${ }^{2}$ (Fig. 7).

La ubicación del monasterio debió tener una posición privilegiada en lo que a la caza se refiere, y por ese motivo sería lugar frecuentado por los monarcas. Al menos existe la constancia de la presencia en el monasterio de Fernando el Católico y del emperador Carlos en los primeros años del siglo XVI ${ }^{3}$, y lo cierto es que esa relación con la realeza no debería dejarse de lado a la hora de considerar la ornamentación del conjunto ${ }^{4}$.

Esa situación de reformas y mejora del aspecto externo del monasterio a la que aludimos, llevaría consigo la decoración mural del claustro bajo en una fase posterior, cuyo estudio pretendemos esbozar. La decoración pictórica de este espacio, con la profusión con que se acometería en el último tercio del siglo, sugiere algunas ideas sobre la propia concepción del claustro en la vida de la comunidad. Una de las cosas más importantes y sagradas que hay en las religiones son los claustros..., dirá el padre José de Sigüenza al comenzar la descripción del claustro principal del Monasterio de El Escorial. Es un inicio que no debemos nunca olvidar a la hora de reparar en lo cuidada que habría de ser la ornamentación de un lugar donde corren las leyes del silencio y otras observancias ${ }^{5}$.

El claustro es considerado como un auténtico ámbito sacro. Por él transcurren las múltiples procesiones que tienen lugar a lo largo del año litúrgico; es el lugar de meditación y descanso de los monjes, el eje distribuidor de sus vidas ${ }^{6}$. La práctica de la lectio divina tenía lugar en la crujía paralela a la iglesia, en la misma zona donde se celebraba lo que se conocía como mandatum, el lavatorio de los pies a los monjes, en la tarde del Jueves Santo, que terminaría por dar nombre a ese espacio. Es en esta crujía donde se conservan más restos de lunetos pintados, coincidiendo con los temas pasionales que rememoraba el calendario.

\footnotetext{
1 Francisco Antón: «Monasterios medievales de la provincia de Valladolid. Santa María de Valbuena», Bol. de la Soc Española de Excursiones, t. XXX, Madrid, 1922, págs. 160-205. Posteriormente incluiría el estudio monográfico sobre el Monasterio en su obra Monasterios medievales en la provincia de Valladolid, Valladolid, 1942, págs. 908 y ss. Sobre el dominio monástico y los bienes del monasterio está publicado el estudio histórico de M. Jesús Ortega González: Santa María de Valbuena. Un monasterio cisterciense a orillas del Duero (siglos XII-XV), Valladolid, 1983.

2 Sobre la reforma arquitectónica de este espacio en el siglo xvı, Antonio García Flores: “Santa María de Valbuena, Valladolid, en el siglo xvI: transformación y ampliación del claustro medieval», en I Congreso nacional sobre humanistas españoles. Humanismo y Císter, León, 1996.

3 Rafael Domínguez Casas: Arte y Etiqueta de los Reyes Católicos. Artistas, residencias, jardines y bosques, Madrid, 1993, págs. 285-286.

4 Sobre la ampliación del claustro alto y su relación con un posible mecenazgo regio en época de Carlos V puede resultar sugerente consultar la obra de Pablo de la Riestra, El claustro de las comendadoras de Santiago en Valladolid y el patio Welser de Nuremberg (Patios con arquerías españoles y alemanes en torno al 1500), Valladolid, 1994.

5 Fray José de Sigüenza: Tercera parte de la Historia de la Orden de San Jerónimo, Madrid, 1605. En este caso la cita la tomamos de la parte titulada La Fundación del Real Monasterio de San Lorenzo de El Escorial, Madrid, 1963 , pág. 228.

$6 \mathrm{Al}$ respecto dice Lekai: "el claustro fue siempre la arteria vertebral de la vida monástica, comunicando entre sí las partes vitales del edificio. Alli realizaban los monjes sus tareas domésticas, su Lectio Divina o Meditatio, donde pasaban sus ratos libres y donde a veces se les permitía conversar; en una palabra, era el cuarto de estar monástico, lleno de aire, luz y soln, Louis J. Lekai: Los cistercienses. Ideales y Realidad, Barcelona, 1987, pág. 348.
} 


\section{El ciclo de la vida de Cristo y otros temas devocionales}

La plasmación de un ciclo iconográfico concreto en el claustro del monasterio de Valbuena reclamó la existencia previa de un programa marcado por la propia comunidad, que respondiera plenamente a sus necesidades. Los restos que hoy se conservan de esta decoración mural sí aparecen siguiendo un programa unitario en la crujía del mandatum. Las pérdidas totales de la superficie pictórica en otros lunetos y el encalado de algunos más, que permiten adivinar la presencia de otras escenas, impiden en estos momentos la reconstrucción completa de la narración.

Dos lunetos más, conservados con grandes deficiencias, en la esquina situada entre el parlatorium y el calefactorio, plasman dos escenas diferentes que rompen el ciclo pasional del mandatum. Hablamos de la penitencia de San Jerónimo y del celebrado episodio de la Lactación de San Bernardo, que no podría faltar en un cenobio cisterciense y que además era un importante punto referencial a la hora de regular la vida litúrgica de los monjes y su transcurrrir en el claustro.

En principio, por tanto, y con las dificultades que entraña el estado de conservación que impide llegar al fondo de la reconstrucción decorativa, parece que el ciclo pasional finalizado con la Resurrección gloriosa decoraría tan solo la crujía paralela al templo monástico, empleándose otro programa narrativo diferente en las otras tres alas. Lo cierto es que se trata de una hipótesis difícil de creer, en la que entran en juego muchas circunstancias. La desaparición completa de restos pictóricos en los lunetos de la crujía oeste impide saber si en algún momento estuvieron decorados con frescos del mismo ciclo que hoy contemplamos en el claustro del mandatum. Las otras dos crujías han sufrido variaciones. En el caso de la que da paso al refectorio la presencia de lunetos todavía encalados dificulta la reconstrucción e incluso el hecho de comprobar si sobre las pinturas anteriores se llevaron a cabo repintes. En la crujía este las propias reformas estructurales que tuvieron lugar en el siglo xviII y que transformaron la sala capitular en sacristía, pudieron generar una serie de modificaciones, acusadas con mayor fuerza en la decoración mural. La pintura de las bóvedas, en todo este ámbito, se observa profundamente repintada con seguridad coincidiendo con ese momento de mejoras.

Lo más lógico es que la decoración de la totalidad de los lunetos del claustro correspondiera a un programa unitario que a juzgar por los restos reflejaría la vida de Cristo, como actualmente se puede comprobar en conjuntos magníficos como los que decoran el Claustro de los Evangelistas de El Escorial. En ningún caso esta situación impediría que en las esquinas se plasmaran otras escenas devocionales ligadas a la vida espiritual de la orden, como la Lactación o la imagen intelectual y sapiente de San Jerónimo. Carducho no hace más que señalar con claridad la evidencia de la adecuación figurativa con el espacio en que se iba a disponer, tal y como hicieron tantos tratadistas del momento y como sin duda lo contemplamos en Valbuena si es Templo, Claustro, ó Oratorio, claro está que todo quanto se ha de pintar en su uso y adorno, serán historias de la vida, y muerte de nuestro Señor Iesu Christo, de su Santisima Madre, y Santos que están gozando, y asistiendo a Dios.... Hase de atender a la avocación de la iglesia, y devoción del Patrón 7 .

El recorrido por los lunetos que conservamos referidos a la vida de Cristo se inicia hoy en el episodio del Prendimiento (Fig. 1), del que apenas se mantiene un pequeño pero espléndido y movido fragmento en el que podemos observar a San Pedro en el ataque al criado del Sumo Sacerdote que narran las Escrituras ${ }^{8}$. Mayores son los restos conservados del episodio siguiente,

\footnotetext{
7 Vicente Carducho (edición y notas de Francisco Calvo Serraller): Diálogos de la Pintura, Madrid, 1979 (la primera edición es de 1633), pág. 327.

8 Todos los evangelistas mencionan el episodio, pero es San Juan, 18, 10-11, el que proporciona más detalles: "Entonces Simón Pedro, que llevaba una espada, la sacó e hirió al siervo del sumo Sacerdote, y le cortó la oreja derecha. El siervo se llamaba Malco. Jesús dijo a Pedro: vuelve la espada a la vaina...».
} 
Jesús ante Pilatos (Fig. 2), del que tenemos la suerte de conservar una fotografía antigua en la que podemos seguir con detalle la composición, desarrollada en un interior arquitectónico. La narración sigue el capítulo de San Mateo en la plasmación de la escena tanto en el lavatorio de manos del magistrado ante el pueblo como en la presencia discreta de su mujer en el quicio de la puerta, quien le había hecho llegar su presentimiento sobre la justicia del reo ${ }^{9}$.

La deteriorada Crucifixión reproduce el repetido instante del Calvario en que Cristo aparece flanqueado por su Madre y por San Juan, de acuerdo con el texto del evangelista ${ }^{10}$ (Fig. 3). La serenidad caracteriza la representación, con influencia de las composiciones de Miguel Ángel. El tema de la Piedad (Fig. 4), fuera de los ciclos evangélicos, tiene un origen en la tradición medieval, vinculado a las visiones de los místicos alemanes de los últimos años del siglo XIII, y alcanzaría una gran devoción en toda Europa. Son célebres las palabras de San Bernardo, que el santo pone en los labios de la Virgen: Lo estrecharé entre mis brazos, y depuesto de la cruz, besaré a mi Hijo, Dios y Señor ${ }^{11}$. La cita habla por si misma cuando se trata de la decoración de un espacio cisterciense. El modelo a seguir dispone al grupo en una típica composición triangular, con la figura poderosa de la Virgen sosteniendo a un Cristo que descansa sobre el suelo, en esa evolución formal hacia lo barroco que caracteriza al tema. En un segundo plano, pero perfectamente visible, junto a la deliciosa visión paisajística de Jerusalén, tiene lugar el entierro con el cuerpo de Cristo completamente envuelto en telas.

El episodio final, en el último tramo del claustro junto a la puerta que lo comunica con el templo, es la Resurrección (Fig. 5). En la tradición evangélica este tema se ha plasmado de formas diversas para adquirir un esquema muy habitual en el siglo XVI, explicado por Reau como una Resurrección ascensional que especialmente iba a consolidarse en Italia ${ }^{12}$. Cristo asciende triunfante sobre su sepulcro haciendo gala de una impresionante fuerza física y deslumbrando con su luz a los guardianes del sepulcro que caen a sus pies. Es imposible resistir a la tentación de ver en el tratamiento general de la escena y, especialmente en la disposición de ese Cristo de formas poderosas, la huella de las innovaciones miguelangelescas.

Hemos dejado para el último lugar la descripción iconográfica de los dos lunetos (Fig. 8) que mencionamos al comienzo de este capítulo, representando episodios de la vida de San Jerónimo y San Bernardo. El primero de ellos, también conservado a duras penas, tiene explicación por la propia entidad del santo como padre de la Iglesia, fecundo escritor e intelectual cuya devoción estuvo extendida en amplios sectores. Su importancia se acentúa en relación con el episodio de su penitencia en la cueva de Belén, de su soledad y de su importancia para los ideales monásticos ${ }^{13}$. Tampoco estaría de más recordar que fray Martín de Vargas, el gran reformador del Císter hispano, del que Valbuena fue plaza especialísima, había sido fraile jerónimo antes de ingresar en la orden de los monjes blancos y estaría imbuido por las personalidad del gran exégeta y su orden, que no dejarán de marcar su reforma.

En cuanto a la representación de la Lactación de San Bernardo la razón de su presencia en el claustro es evidente a la hora de cumplir funciones devocionales y litúrgicas. Los propios Usos de la orden señalan como parte importante del ritual sabatino la importancia de la escena: En llegando los menores a el Quadro, que debe haber en el Claustro, en que esté pintado el milagro de la leche que, dio María Santísima a N.P.S. Bernardo, todos se arrodillarán, y cantarán la Estrofa Mons-

\footnotetext{
9 Mateo, 27, 11-26.

10 San Juan 19, 26.

11 Manuel Trens: Maria. Iconografía de la Virgen en el arte español, Madrid, 1947, págs. 204-222.

12 Louis Reau: Iconographie de l'art chrétien. Iconographie de la Bible. II. Nouveau Testament, París, 1957, págs. 547-

13 Santiago de la Vorágine: La leyenda dorada, t. II, Madrid, 1982, págs. 630-635.
} 549. 
tra te esse Matrem... ${ }^{14}$. El texto dice que debe haber en el Claustro, requiriendo la presencia física de la representación para cumplir con una ceremonia que se celebraba todos los sábados del año. Estilísticamente este sería el único luneto conservado que se aparta de la idea general. No se enmarca en un óvalo como los demás imitando arquitecturas, sino que se adapta perfectamente al espacio triangular. El concepto de la figuración proviene de esquemas italianos, pero diferentes y anteriores al resto del programa. Una obra en la que intervendrían muchos pintores puede acusar este tipo de diferencias estilísticas y más si quien la ejecuta es un taller que recibe modelos desde Italia, de épocas diversas pero con éxito devocional.

\section{El enmarcamiento de las escenas y sus peculiaridades}

Al igual que las propias escenas también el enmarcamiento de cada una de ellas ha llegado con pérdidas hasta nuestros días, en algunos casos demasiado grandes para permitirnos reconstruir el marco original.

El esquema seguido en Valbuena crea una disposición específica para diferenciar la escena, evitando la simple adaptación al marco arquitéctónico estructural. Se trata de crear una arquitectura ficticia con una moldura en la que se colocan discretos motivos ornamentales, y que responde siempre a una forma oval. El óvalo permite aislar la composición y definir su desarrollo incorporando un carácter más decorativo a todo el ciclo. No se emplea todo el espacio triangular del luneto en plasmar la escena. Aislada en el marco oval se crea un mayor efecto de ilusión ornamental y se pueden además incorporar otros motivos en los espacios resultantes del desajuste entre el marco y el espacio arquitectónico.

No cabe duda que el recurso entra dentro de los principios de la ornamentación empleada en los ámbitos derivados del manierismo romano y que se hizo muy habitual dentro de las decoraciones murales de los diferentes espacios palaciegos que tanto destacaron en Italia.

El uso de este tipo de marcos se generaliza tanto en pintura como en estuco y su desarrollo va a ser importantísimo para valorar el sentido puramente decorativo que rodea los distintos mensajes iconográficos, hasta que se instale esa renovación purista de las formas que reclamará una mayor atención en el tema ajustándose a la ortodoxia.

El marco oval es una constante en la decoración mural italiana a partir de la mitad del siglo XVI, dentro de unos esquemas decorativos de gran éxito. Su empleo es destacado por ejemplo, en los frescos de Vasari ejecutados en el Palazzo Vecchio de Florencia entre 1556 y 1562. También interesa en esta ocasión el uso de la forma oval en las labores llevadas a cabo por el Bergamasco antes de su partida hacia España, como el ciclo de frescos de la Villa delle Peschiere en Génova donde interviene en torno a $1560{ }^{15}$. En las diferentes estancias se siguen los modelos derivados de Miguel Ángel y difundidos a través de los grabados de Beatrizet y de Salviati. En fin una buena parte de los motivos proceden de los decoradores de la escuela de Fontainebleau, donde toma cuerpo mucha de la ornamentación secundaria que se reproduce tanto en las estructuras arquitectónicas como pictóricas de la segunda mitad del siglo.

14 Ritual cisterciense, comúnmente llamado Usos..., Valladolid, 1786, pág. 297. Lo tardío de la edición pensamos que no interfiere demasiado en una ceremonia que con seguridad formó parte del ritual del Císter desde fecha temprana. Agradecemos este dato al Rvdo. D. José Luis Velasco, párroco actual de Santa María de Valbuena, estudioso y entusiasta del Monasterio que tantas atenciones nos dispensa poniendo a nuestra disposición ese insigne conjunto.

15 Giuseppe Rosso del Brenna: "Giovanni Battista Castello", en I pittori bergamaschi. Il Cinquecento, II, Bergamo, 1976, págs. 377-511. Algunos modelos de marcos ovales, como los que se reproducen en las páginas 424 y 425 , encajan perfectamente con lo que se realizará en Valbuena. El esquema no hace más que seguir los planteamientos decorativos de los artistas que trabajan en Fontainebleau, de lo que existen tantos ejemplos, según se puede observar en la decoración de los retratos de los Doce Césares que realiza Andrea Schiavone (Henry Zerner, ed., Italian artists of the sixteenth century, school of Fontainebleau, The illustred Bartsch, 32, New York, 1979, págs. 112-123). 
Ya en España el marco ovalado es el elegido en buena parte de las decoraciones murales que se ejecutan en los ámbitos residenciales. Y en este sentido viene al caso la narración plástica de la historia mitológica de Perseo en el palacio del Pardo, pintada bajo la dirección de Becerra y con la participación de su equipo tanto hispano como genovés. Las escenas del ciclo que se colocan en las esquinas del techo emplean el marco ovalado, en este caso no pintado sino realizado con estucos. El parentesco con alguno de los esquemas de marco utilizados por el Bergamasco en Génova es evidente. La importación de esta tipología ornamental afecta a la decoración del claustro de Valbuena y una de las vías de entrada no puede estar en otro sitio que en la decoración de los espacios cortesanos, donde como artífices o como atentos espectadores han tenido que participar de algún modo los artistas que acometen el encargo.

Si en la mayor parte de los casos, además de la contemplación directa, no debemos olvidar la difusión de los elementos decorativos a partir de los grabados, en esta ocasión resulta sugerente señalar como ese modelo de marco oval decorado con motivos arquitectónicos y empleando las vueltas de los cueros recortados es el utilizado en la edición italiana de la Anatomía del doctor Valverde de Amusco. En 1556 se edita esta obra con grabados que se han venido atribuyendo a Becerra tradicionalmente ${ }^{16}$, en los que de nuevo observamos el uso de esa cartela oval como la que se va a emplear en Valbuena. La relación de Becerra con Valladolid y la secuela de su estilo en las pinturas que estudiamos pueden servirnos a la hora de buscar las raíces de la utilización de esos motivos.

Apuntamos como el marco oval creaba un desajuste con el espacio triangular del luneto, generando unos espacios aprovechados para introducir otro tipo de motivos ornamentales que colaboran en la creación de un espacio ilusionista, junto a las máscaras y a otros elementos del vocabulario decorativo del manierismo que se manifiestan con profusión en la decoración de las bóvedas. La utilización de telones de fondo se repite en los distintos pasajes del ciclo. Tanto los putti como las figuras monstruosas, derivadas del onírico mundo del grutesco, colaboran en esa tarea teatral ayudando a descorrer cortinajes blancos, rojos o azules, y mostrar así a los espectadores, como en un escenario, los episodios pasionales.(Fig. 8.)

Debido a las perdidas pictóricas sólo podemos contemplar algunas de esas figuras, mitad tenantes mitad guardianes, que son la más clara expresión de ese afán ornamental, esteticista y fantástico que tiñe la decoración de los lunetos. Al lado de los putti de la escena de Jesús ante Pilatos o de la Piedad, una figura femenina de cola de pez en el Prendimiento y dos tritones alados entre guirnaldas de frutas, en la Resurrección, ofrecen un reducido pero elocuente repertorio figurativo que prueba ese regodeo en lo ornamental, un mundo de contrastes entre belleza ideal y feísmo propio del manierismo, y permite la relación con los sistemas decorativos palatinos en la España de la segunda mitad del siglo XVI.

\section{Las bóvedas: planteamiento decorativo y motivos ornamentales}

El proyecto ornamental del claustro bajo de Valbuena no acababa con la decoración figurada de sus lunetos, con la representación de todo un ciclo temático al servicio de la contemplación comunitaria y de la meditación, a pesar de la variedad de los recursos decorativos que no son más que el testimonio de una época. Se decorarán además los zócalos y la parte interior de las arquerías, según permiten ver los escasos restos conservados. Todas las bóvedas sufren ade-

16 Chandler R. Post: A History of Spanish Painting. The Later Renaissance in Castile (Ed. by Harold Wethey), Harvard University Press, 1966, Kraus reprint, New York, 1976, págs. 148-180. 
más una total transformación, abandonando su segura desnudez primigenia para cubrirse por completo con variados y caprichosos motivos pictóricos.

Mascarones, cartelas con paisajes y mitos clásicos, seres híbridos y arquitecturas fingidas llenaron plementería y nervios de las bóvedas, portando un singular espíritu ornamental que resulta enormemente llamativo en el ambiente austero de una orden que camina por unas vías, diferentes del rigorismo inicial pero acorde con el espíritu renacentista (Fig. 6).

El desarrollo de los grutescos en la decoración del siglo xvi ha sido muy debatido, desde el origen de su utilización a partir de su descubrimiento arqueológico hasta la profundidad de su significado ${ }^{17}$. Desde los primeros hallazgos las decoraciones que aparecían en las ruinas de la Roma clásica comenzaron a difundirse a través de artistas y grabadores como Giovanni Antonio da Brescia, colaborando en una nueva mentalidad ornamental.

A pesar de que las pérdidas pictóricas son tan abundantes en las bóvedas (Fig. 9) de Valbuena como en los lunetos, en el recuerdo está con claridad la decoración de las loggias vaticanas de Rafael y Udine que, desde fecha muy temprana pasaron a engrosar ese catálogo de formas que recorrió Europa con grabados como los de Marcantonio Raimondi. El eco de estos motivos romanos se haría sentir en las más diversas tipologías artísticas, no sólo en la decoración arquitectónica. Sepulcros y retablos cubrirían sus superficies con estas caprichosas figuraciones.

La libre interpretación del vocabulario clásico, la ruptura y el ilusionismo se manifiestan en los motivos empleados en la decoración de las bóvedas. Quizás el punto de referencia obligado, al que estamos aludiendo siempre que el tema es el arte español de la segunda mitad del siglo XVI, sea el monasterio de El Escorial. La reflexión que, sobre los grutescos escurialenses desarrollara el profesor Checa, pensamos que es válida a la hora de aplicar el mismo método a la decoración de Valbuena ${ }^{18}$. El uso de arquitecturas fingidas se convierte en uno de los elementos ilusionistas con más fortuna en el campo del grutesco. Son construcciones frágiles, imposibles e ilógicas, que rompen con los órdenes clásicos y que suponen un juego de ficción fantástico e imaginativo que contraviene todas las leyes físicas.

Lo monstruoso es al mismo tiempo idea recurrente en estos parámetros ornamentales, donde los seres híbridos se presentan con naturalidad en un alarde de imaginación maravilloso. Esos extraños seres se ocultan tras las arquitecturas, se mimetizan con ellas, las sostienen y se convierten en los auténticos ocupantes de un mundo fabuloso, de un juego permanente. ¿Qué hacen en vuestros claustros en donde los religiosos se consagran a las lecturas sagradas, esos monstruos grotescos, esas extraordinarias bellezas deformes y esas bellas deformidades? había dicho San Bernardo en el texto de su Apología a Guillermo, tantas veces repetido ${ }^{19}$. Estaba claro que los tiempos eran otros y de nuevo la imagen y la fantasía accedían con impunidad a los claustros olvidando ese inicial rigorismo iconoclasta.

El concepto del ilusionismo manierista y de la visión de la naturaleza favoreció además la entrada del paisaje, aislado y decorativo, dentro de los espacios arquitectónicos, como ventana abierta a una ilusión óptica donde no sólo cabía el mensaje racional que marcaba la autoridad espiritual, sino también la divagación estética y el capricho. En los propios lunetos y en un segundo plano, podemos comprobar además el avanzado tratamiento que se dispensaba al paisaje

17 Sobre este tema y en general sobre toda la problemática del manierismo pensamos que sigue siendo una interesante y breve síntesis, a pesar del paso del tiempo, el trabajo del profesor Alfonso Rodríguez G. de Ceballos: "Manierismo como constante o como estilo", Revista de Ideas Estéticas, núm.130, t. XXXIII, Madrid, 1975, págs. 95-108. El inicio del uso del grutesco en el Renacimiento queda perfectamente reflejado en la obra clásica de Nicole Dacos, La découverte de la Domus Aurea et la formation des grotesques a la Renaissance, London, 1969.

18 Fernando Checa Cremades," Capricho y fantasía en El Escorial (Sobre el grutesco y el gusto por lo fantástico en el Monasterio)», Goya, núm. 156, Madrid, 1980, págs. 328-335.

19 Georges Duby, San Bernardo y el arte cisterciense (El nacimiento del gótico), Madrid, 1981, pág. 113. 


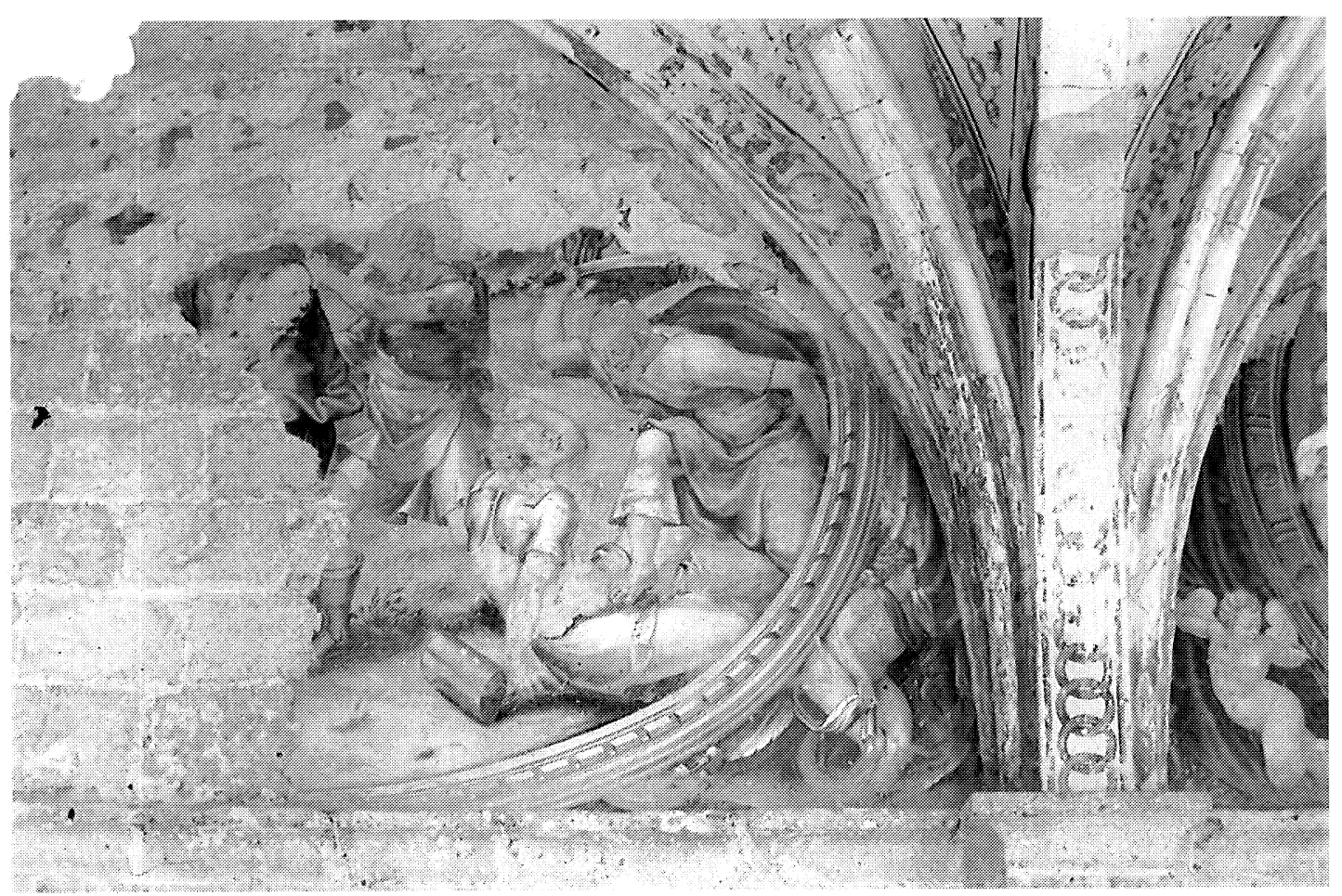

Fig. 1. Fragmento conservado del Prendimiento. Claustro del monasterio de Valbuena de Duero.

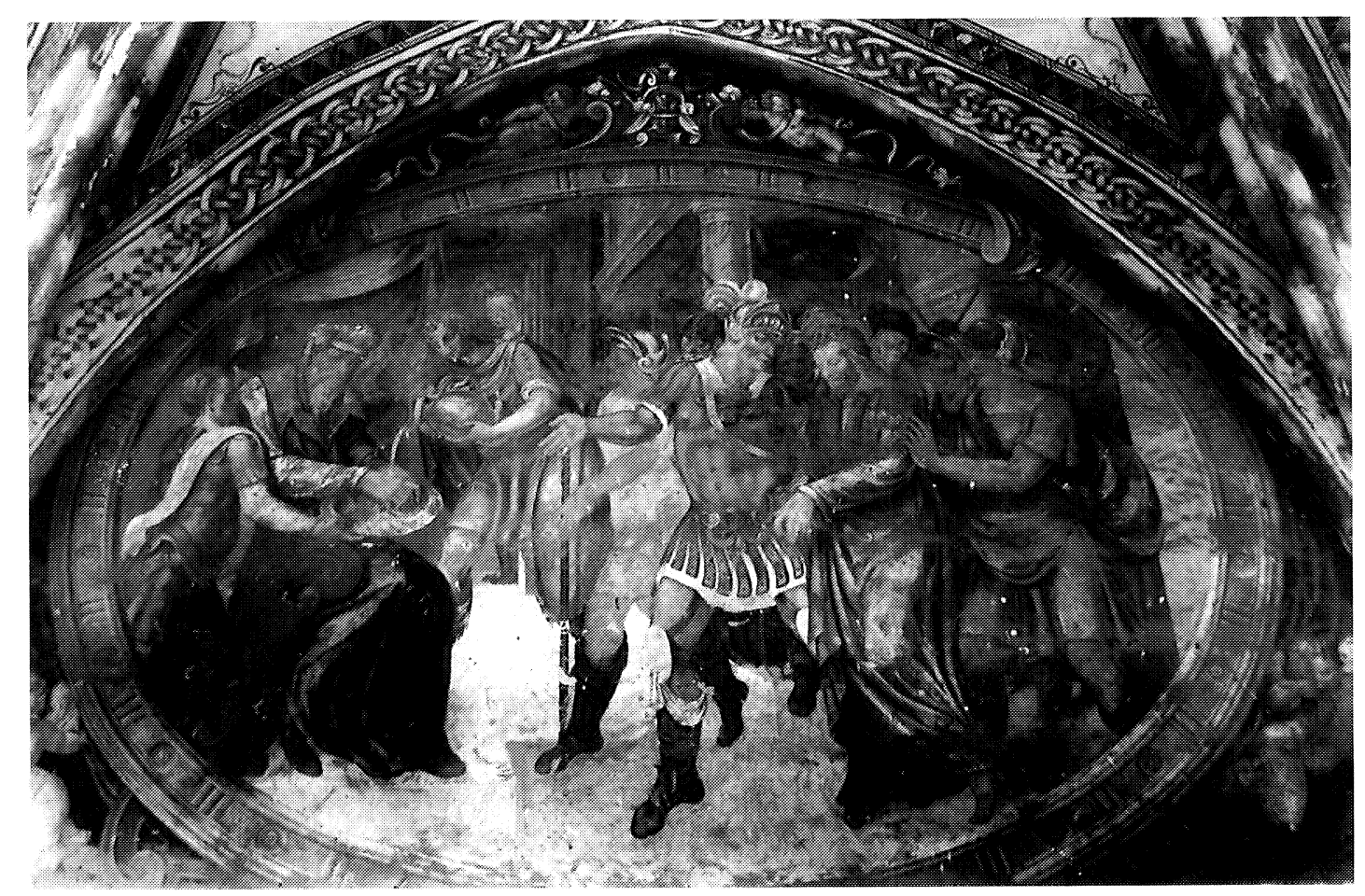

Fig. 2. Jesús ante Pilatos. Claustro del monasterio de Valbuena de Duero. Foto Archivo Mas, Barcelona. 


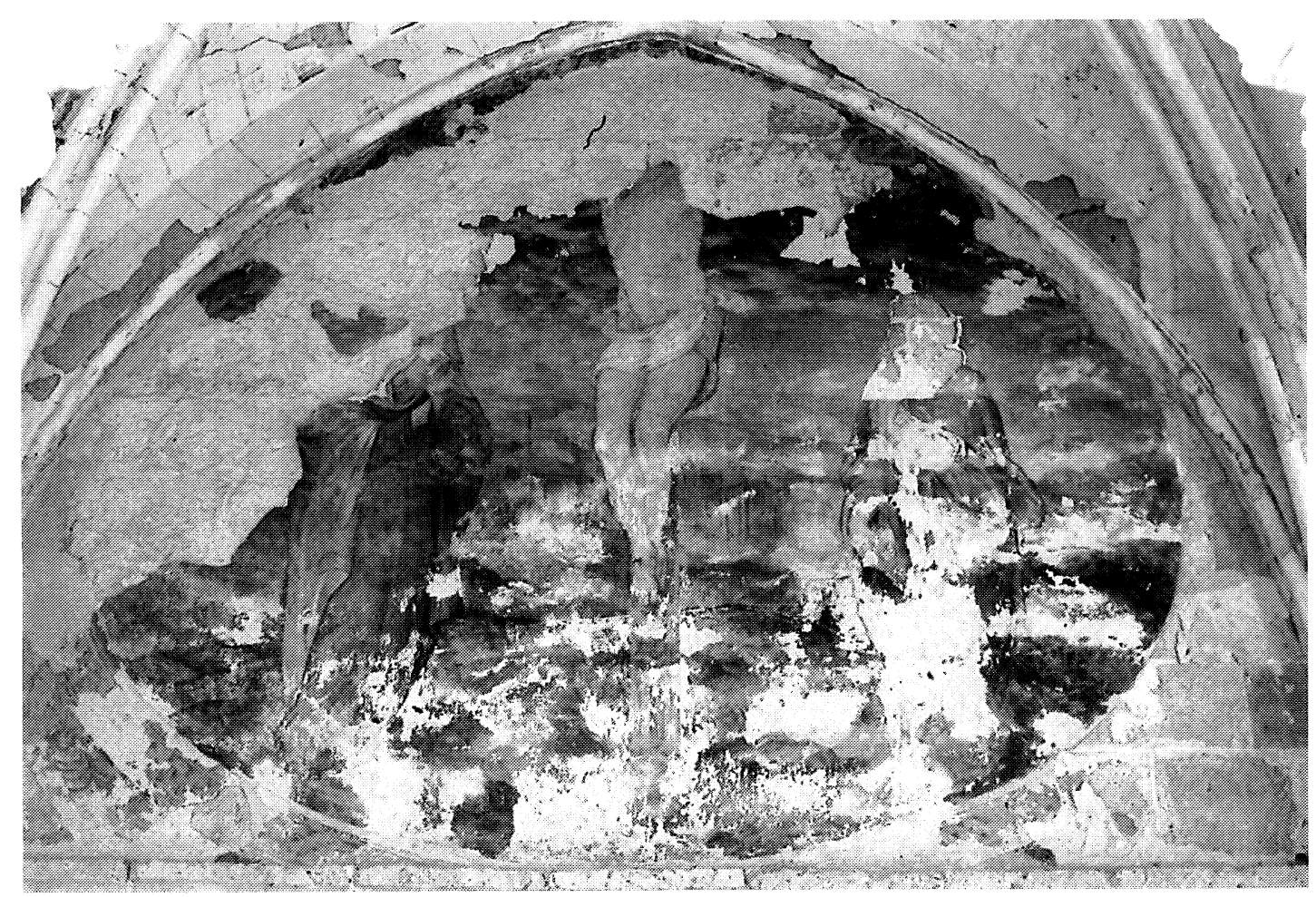

Fig. 3. Calvario. Claustro del monasterio de Valbuena de Duero.

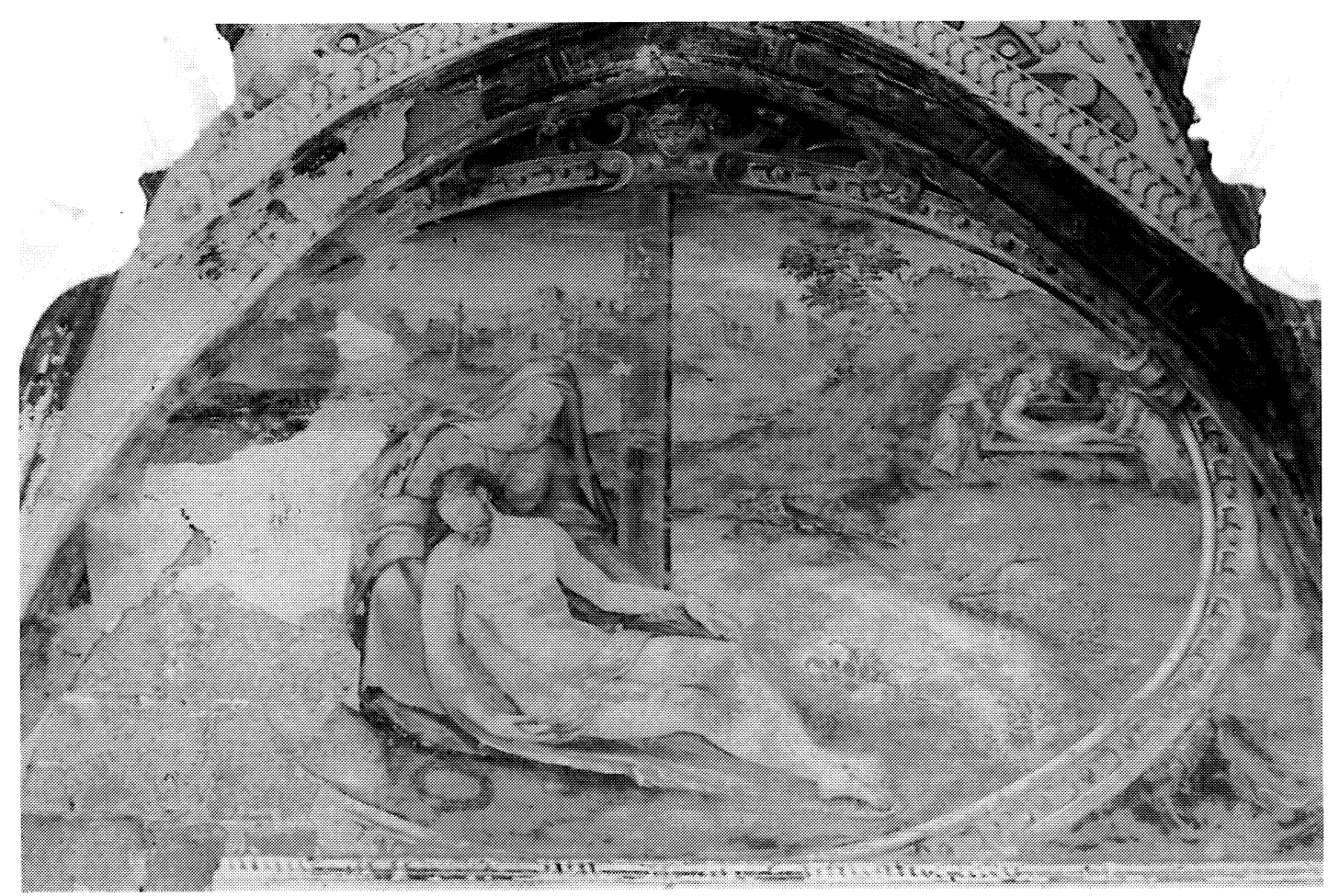

Fig. 4. Piedad y entierro de Cristo. Claustro del monasterio de Valbuena de Duero. 


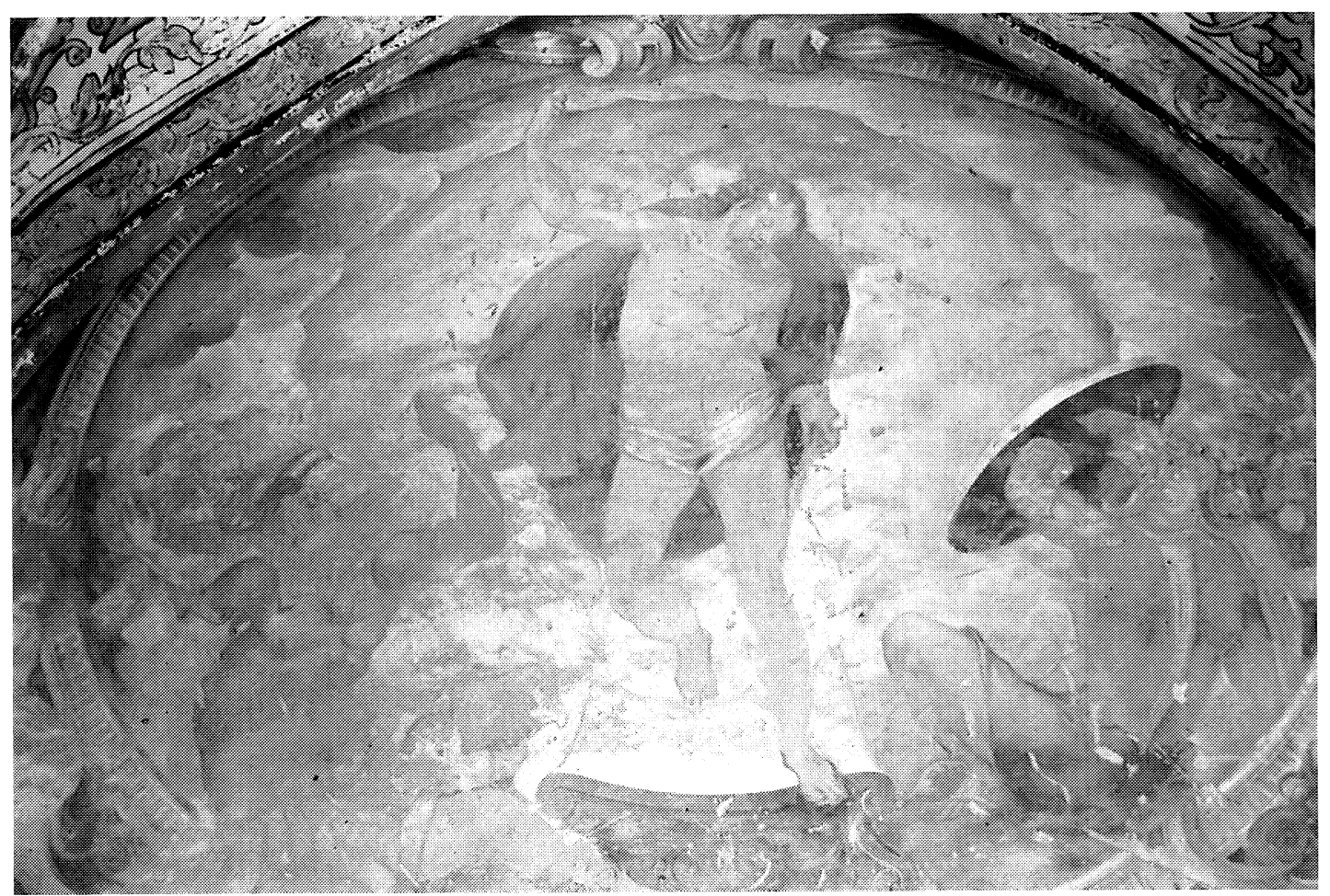

Fig. 5. Resurrección. Claustro del monasterio de Valbuena de Duero.

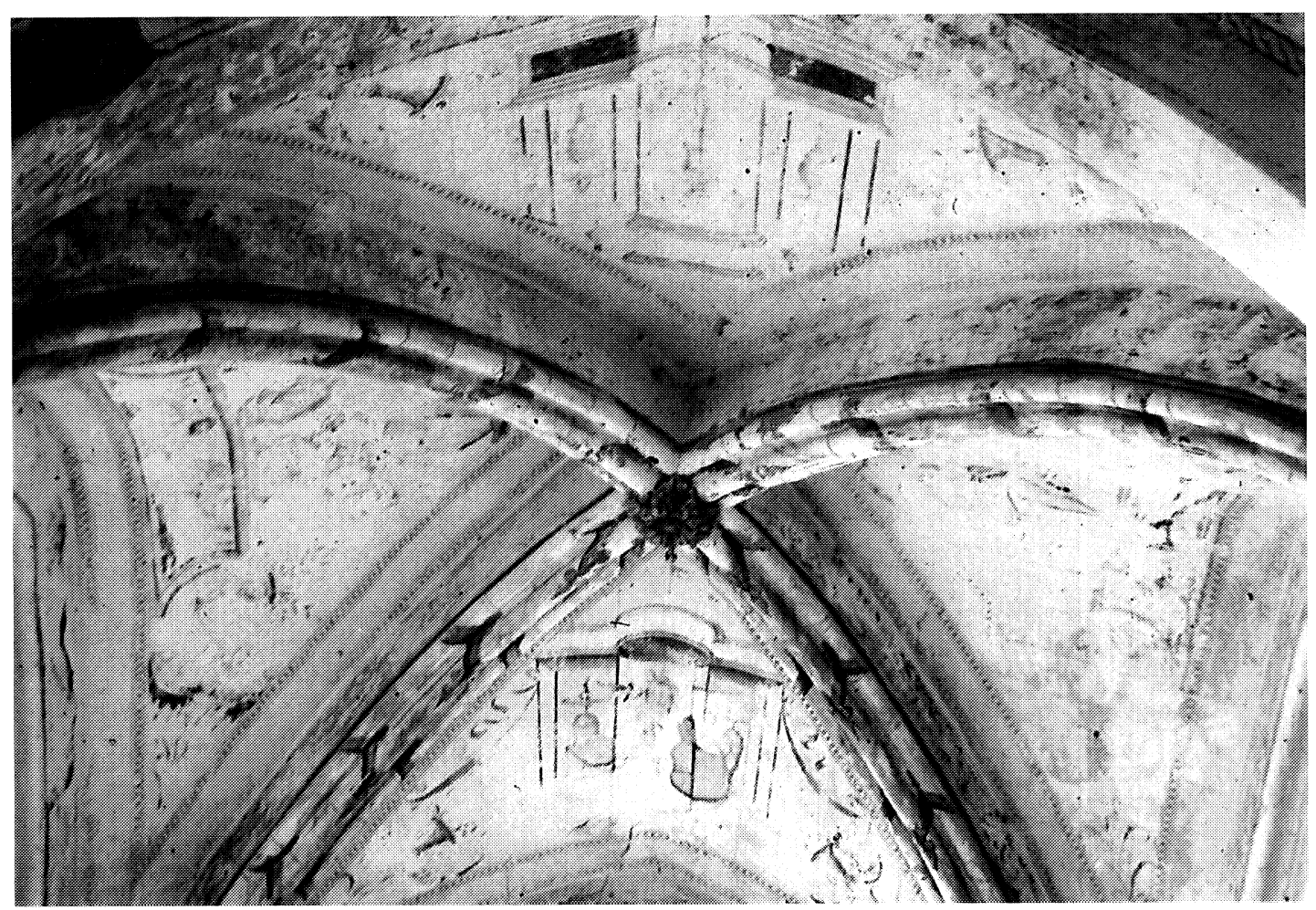

Fig. 6. Detalles de las bóvedas del claustro bajo. Monasterio de Valbuena de Duero. 

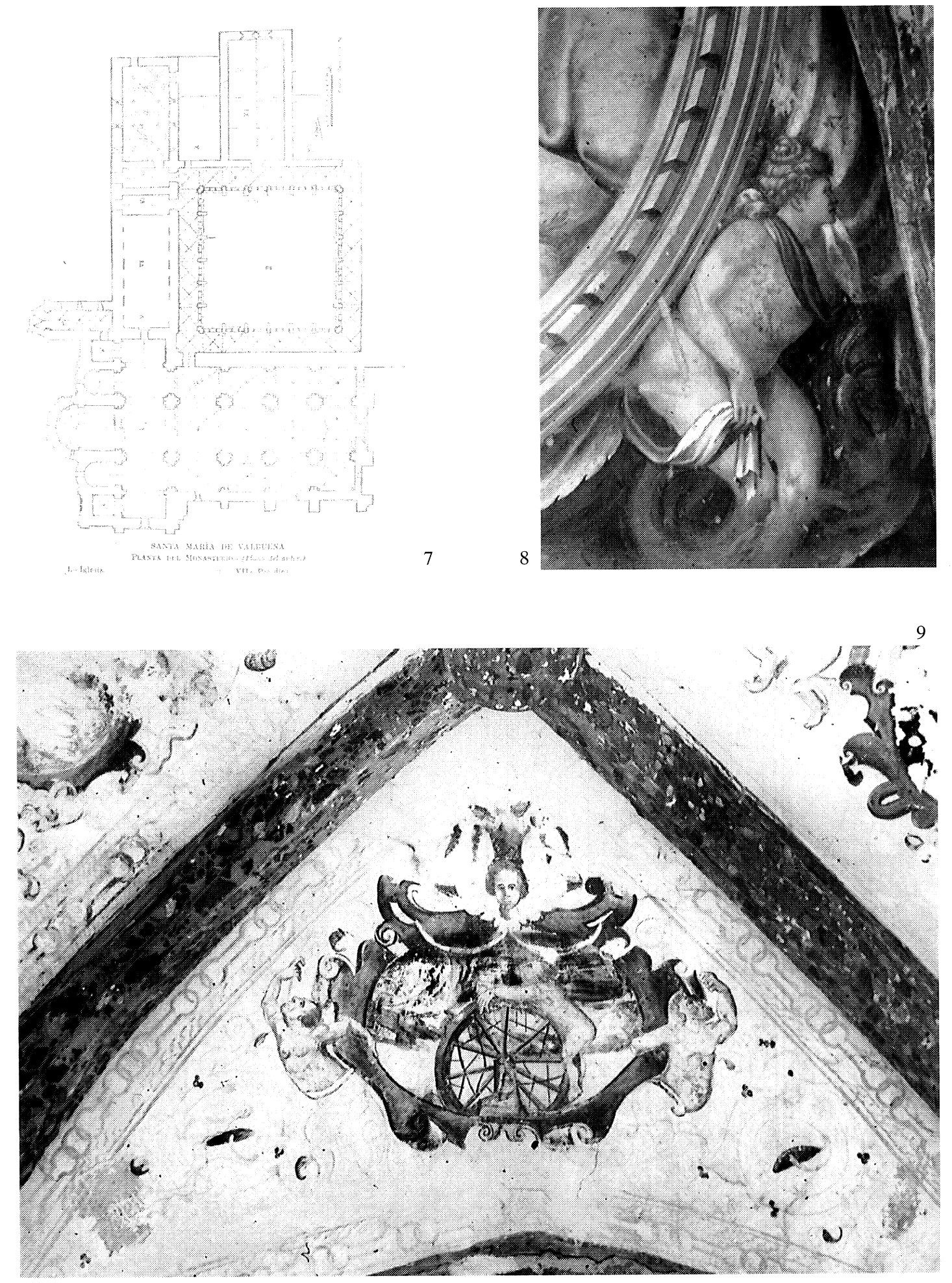

Fig. 7. Plano del monasterio de Valbuena de Duero, según Francisco Antón.

Fig. 8. Enjuta de uno de los lunetos decorados. Monasterio de Valbuena de Duero.

Fig. 9. Detalles de las bóvedas del claustro bajo. Monasterio de Valbuena de Duero. 
en el fondo de las escenas, con la reconstrucción de ciudades o la inclusión de ruinas clásicas, con un tratamiento que recuerda las mismas visiones en las citadas escenas que, sobre la fábula de Perseo, pintara Becerra en el palacio del Pardo. Fernando Marías habla de la entrada del paisaje en el arte español a partir de una situación subsidiaria de imágenes decorativas, ambientales, vinculadas a un mero deseo de ilusionismo, fechando en la década de 1580 los primeros paisajes, curiosamente en pinturas al fresco realizadas por italianos en palacios como los del Infantado o El Viso del Marqués, dos de los conjuntos de pinturas murales más destacados de nuestro país ${ }^{20}$.

Sutilmente encontramos en las bóvedas alusiones directas al mundo de la mitología clásica en la representación de las figuras desdichadas de los Condenados, y en los que no queremos ver más que un mensaje moralizado que se usó abundantemente en el Renacimiento ${ }^{21}$. Los suplicios de Sísifo, Ticio, Tántalo o Prometeo ilustran el castigo divino a la osadía de los hombres y a su vanidad, en una idea que fácilmente se puede traspasar al servicio del cristianismo.

El empleo de los textos en la línea de la literatura emblemática encaja con los gustos del momento y recuerda el carácter del ámbito claustral como espacio de meditación y recogimiento, donde la valoración de estas empresas tendría un significado pedagógico.

Junto al mensaje claro y rotundo de las escenas que se disponen en los lunetos, los grutescos y la decoración de las bóvedas colaboran en la conformación de un espacio ornamentado en el que transcurre la vida diaria de la comunidad. La creación de este ambiente ilusionista y fantástico, lúdico y evasivo es lo que parece llevar al recuerdo de ambientes cortesanos en los que este género se desarrolló.

Ha sido el mismo Checa quien al hablar de los grutescos de El Escorial, se plantea el problema del recuerdo de lo cortesano para detenerse en las diferentes opiniones que, sobre la validez iconográfica de su uso, fueron vertidas a lo largo del siglo xvi. Creemos que sus conclusiones para explicar la presencia de estos divertimentos en el bastión de la arquitectura contrarreformista, pueden ser perfectamente aplicables a Valbuena: Una explicación a la aparición de estos motivos en un centro religioso es el carácter de código de significación débil que tienen: aunque su contenido sea preferentemente de carácter pagano y laico, sus significados no transmiten mensajes en un sentido fuerte, sino que se reduce a la creación difusa de un ambiente alegre y agradable, con leves toque figurativos de elementos religiosos ${ }^{22}$.

El funcionamiento de esta idea se comprueba en los textos de los tratadistas, quienes responden con planteamientos similares, como podemos comprobar en los textos de Carducho, posteriores cronológicamente pero expresando en esencia a idénticas posiciones. Al hablar de la decoración de iglesias o claustros señala: Y si para adorno fuere necesario algunos grutescos, se procure sean compuestos con decoro honesto, y no profano indigno de aquel lugar, usando dellos como pudiera usar una persona mui grave de la gracia y donaire, en dezir, ó contar algún caso (que gracejo viene a ser el grutesco entre historias divinas, ó historias graves) y así se deve usar dellos con tiento, y poco dexándolo para otras partes más esparcidas y humanas ${ }^{23}$.

El programa ornamental de las bóvedas, junto a todo el claustro bajo de Valbuena, es producto de su propio contexto histórico, de la contraposición y la distorsión manierista; de un atenuado rigor cisterciense y de composiciones mesuradas pero festivas y caprichosas; de la secuencia ortodoxa y de la fantasía creativa.

20 Fernando Marías, El largo siglo xvı, Madrid, 1989, pág. 579.

21 Este tono moralista es el que presentan los Condenados que pintara Tiziano para la reina María de Hungría y que pasan a las colecciones de Felipe II en 1558. Fernando Checa, Tiziano y la monarquía hispánica, Madrid, 1994, págs. 9192, 263-264.

22 Fernando Checa, «Capricho y fantasía..., pág. 333.

23 Vicente Carducho: op. cit., pág. 327. En nota, Calvo Serraller apunta en esta edición algunos comentarios sobre la validez de la decoración de grutescos en los espacios sagrados y su fortuna historiográfica. 


\section{Cronología y posibilidades de autoría de los frescos}

A la hora de plantearnos la autoría del guión decorativo del claustro de Valbuena topamos con la barrera infranqueable de la ausencia documental. Buena parte del archivo del Monasterio, disperso a raíz del proceso desamortizador, fue a parar al Archivo Histórico Nacional de Madrid, donde en la actualidad se conserva. Ningún testimonio hay en él de los gastos acarreados por la fábrica monacal, de las reformas estructurales o decorativas de las dependencias monásticas en el periodo que estudiamos ${ }^{24}$. Nos movemos siempre en el terreno de la hipótesis, del análisis estilístico y de la comparación, mientras no aparezca ningún instrumento documental que permita atribuir con seguridad las intervenciones.

Hasta el momento apenas se ha reparado en la consideración de los frescos claustrales de Valbuena, con la excepción de menciones escuetas. En 1922 Francisco Antón, especialmente atento a la arquitectura, señalaba las dificultades que presentaba el claustro monástico para su estudio por estar enlucido y con pinturas al fresco que fechaba entre los siglos XVI y XVII ${ }^{25}$. Enrique Valdivieso dará datos más certeros en el Catálogo Monumental, señalando el manierismo de las composiciones y proponiendo la fecha de su ejecución en torno a 157026.

El interés por el estudio de la decoración claustral surge por su escasez en el ambiente artístico castellano del siglo Xvi. Si bien es cierto que las continuas obras de acondicionamiento de muchas de las iglesias de la región están descubriendo testimonios abundantes de pintura mural, el tratamiento estético de las representaciones responde a un concepto mucho más local que lo que tenemos la ocasión de contemplar en Valbuena. En este caso los motivos decorativos presentan una relación con la decoración áulica, directamente importada de los modelos tan habituales en la ornamentación italiana. Esa unificación entre la temática religiosa y el ornato cortesano es la que se da cita en Valbuena y ahí se encuentra su originalidad.

La introducción de la pintura mural renacentista en Valladolid y su entorno parece hacerse a partir de pintores italianos o de formación italiana, cuya presencia es notable y fructífera a lo largo de todo el siglo, a pesar de que no se haya sistematizado su influencia o su relación con los talleres pictóricos locales ${ }^{27}$. Un ejemplo puede ser el artista romano Antonio Stella, una rescatada personalidad en el Valladolid de final de siglo, amigo de Rabuyate y documentado en unas pinturas murales hacia 1590 dentro del otro gran monasterio del Císter en Valladolid, Palazuelos ${ }^{28}$. Allí se conservarían algunas grisallas realizadas por él sobre temas pasionales, que de forma indirecta, sirven además para situar a Valbuena dentro del contexto de su tiempo.

La pujanza política de Valladolid hasta el definitivo traslado de la corte a Madrid también jugaba su papel en la recepción de artistas foráneos al servicio de las grandes casas nobiliarias que tenían su asiento en la ciudad. Como ya señalara oportunamente Agapito y Revilla, la in-

\footnotetext{
24 En la revisión de la documentación debo agradecer la inestimable ayuda prestada por los jóvenes investigadores F. J. Alonso y Antonio García Flores. Sus estudios doctorales sobre el monacato vallisoletano, desde diferentes puntos de vista, les han llevado a una revisión concienzuda de los fondos documentales de Valbuena, parcos en noticias artísticas hasta los inventarios del siglo xvirI.

25 Francisco Antón: op. cit., pág. 191, "Todas las galerías están planeadas, y en parte, como las bóvedas, pintadas al fresco. Hay obras de composición, de asuntos religiosos, y en las cubiertas motivos renacientes. Estas pinturas serán de entre XVI y $X V I D$.

26 Enrique Valdivieso, Catálogo Monumental de la provincia de Valladolid, Antiguo partido judicial de Peñafiel, t. VIII, Valladolid, 1975, pág. 306.

27 Existen conjuntos en interiores de iglesias de Medina del Campo aunque está por hacer un estudio pormenorizado de la pintura mural de este periodo en Castilla. Al hilo del tema se puede recordar el comentario de Francisco de Holanda: "La Pintura de fresco es muy estimada en Italia y es honrada por M. Micael Angelo en la capilla de Sixto y por otros famosos pintores... Es pintura muy noble y antiquísima y no se sabe hacer en España...", De la pintura antigua (1548), versión castellana de Manuel Denis en 1563, Madrid, 1921, pág. 135.

28 M. A Antonia Fernández del Hoyo: «Antonio Stella, pintor italiano», en BSAA, t. XLVI, Valladolid, 1980.
} 
fluencia del manierismo italiano en la pintura vallisoletana se remonta a la obra de Alonso Berruguete ${ }^{29}$. Si bien es cierto que en torno a los años 30 se detecta la presencia de dos artistas de origen italiano, Julio de Aquiles y Alejandro Mayner, relacionados con la decoración del palacio de Don Francisco de los Cobos y trasladados a Granada ${ }^{30}$, no será hasta mediados de siglo cuando se documente la presencia activa del florentino Rabuyate, instalado durante largo tiempo en la ciudad y trabajando con frecuencia al fresco.

Relacionado con Juan de Juni, su obra se documenta profusamente aunque nada se conserva con certeza, adscribible a su mano ${ }^{31}$. Los testimonios de los artistas de la época permiten hablar de un amplio taller y su nombre aparece asociado a muchos maestros que de algún modo se vinculan en su aprendizaje a las enseñanzas de Rabuyate, particularmente en el caso de la pintura mural. Su volumen de obra es muy grande y su llegada y magisterio marca un momento brillante en la pintura vallisoletana del final de siglo, difícil de precisar por falta de estudios generales. Se ha de tener presente la nutrida colonia de comerciantes italianos que residía en la ciudad y que llegan a tener en ella una influencia destacada en la política y las finanzas. Este grupo puede arrastrar consigo a artistas como Rabuyate, que complacían a sus clientes con las formas de su país de origen, marcando la pauta a la hora de introducir los nuevos esquemas del gusto imperante.

De 1552 data la primera cita documental de Rabuyate pintando al fresco la capilla del banquero Lomelín, un genovés afincado en Valladolid. A partir de aquí son varios los trabajos al fresco realizados por el pintor en distintas iglesias vallisoletanas aunque, en principio, todos hayan desaparecido. En algunos de sus pleitos aparece mención a pintores fresquistas que habían aprendido la técnica en su taller y que sin duda colaborarían con el maestro en trabajos de gran envergadura, como el de la decoración de un claustro. A esto habría que añadir la frecuencia del empleo del fresco en Italia, una técnica fundamental y muy extendida por toda la península con singular fortuna.

El análisis somero de los fondos pictóricos que almacenaba el artista en su codicilo testamentario en 1589, permite descubrir la personalidad de un auténtico comerciante que dispone de obras de diferente temática, soporte y formato para abastecer a su clientela. El desarrollo de este comercio requería la presencia de un gran taller encargado de realizar la pintura. La herencia dejada a su hijo, manifestada en una selecta colección de cuadros para reproducir, muestra la importancia de este sistema de reproducción artística en el contexto de la segunda mitad del siglo XVI, al servicio de una introducción de la moda italiana en Castilla, de vastas consecuencias ${ }^{32}$.

29 La obra de Agapito y Revilla: La pintura en Valladolid, tomo I, Valladolid, 1925-43, es el primer intento por sistematizar la evolución del arte de la pintura en el entorno de la ciudad, desde la Edad Media hasta el siglo xvII. Debemos reseñar aportaciones más recientes con una idea global de síntesis, Jesús M. ${ }^{\text {a }}$ Parrado del Olmo, "La vida de los escultores y pintores en el Valladolid del siglo XVI» en Valladolid, corazón del mundo hispánico. Siglo xvi. Historia de Valladolid, Ateneo, 1981.

30 Martí y Monsó: op. cit., págs. 139-41 transcribe la noticia dada a conocer por Ceán y Pacheco acerca de la presencia de los dos artistas en España. La labor de estos pintores ha sido puesta al día por la doctora López Torrijos en «Los grutescos de Rafael y Udine en la pintura española. La estufa y la logia de Carlos V» en Storia dell'Arte, núm. 60, 1987, págs. 171-183.

31 Martí y Monsó proporcionó muchos datos sobre la importancia de los bienes que deja a su muerte y sobre la trayectoria artística del pintor Rabuyate, no sólo como fresquista o pintor de caballete sino también como artista en decoraciones efímeras muy presente en la vida artística vallisoletana. Agapito y Revilla le dedica un capítulo de su obra La pintura en Valladolid que titula Benito Rabuyate, iniciador de una escuela de pintura en Valladolid. Desde aquí su nombre suena con frecuencia en la bibliografía artística del momento.

32 Sobre el último documento testamentario de Rabuyate vease, Manuel Arias Martínez, «El testamento de Benedito Rabuyate, un pintor florentino en el Valladolid de la segunda mitad del siglo Xvi. Devociones y producción artística», en el catálogo de la exposición Valladolid, la muy noble villa, Valladolid, noviembre y diciembre 1996. 
La amplitud de la superficie pictórica del espacio claustral de Valbuena requerirá sin duda la intervención de un grupo de artistas, haciendo frente no sólo a la pintura de los lunetos sino también de las bóvedas. La participación de talleres es lo más habitual en este tipo de intervenciones iniciando el proceso por la realización de cartones, cuya ejecución era siempre supervisada por el maestro.

Esta será la forma de actuación en otras decoraciones murales de las que poseemos los datos suficientes a la hora de reconstruir la secuencia de su desarrollo. Los distintos proyectos de decoración al fresco de los sitios reales encargados por Felipe II responden a este esquema de funcionamiento. Hasta la muerte de Becerra, al final de la década de los sesenta, su labor es la de un jefe de taller que dispone la tarea a sus oficiales y va marcando las distintas fases del trabajo ${ }^{33}$. Lo mismo sucede en El Escorial con los equipos italianos que trabajan en el ornato pictórico de sus estancias, como queda bien patente en recientes estudios que aclaran y pormenorizan la intervención de los artistas genoveses en el conjunto ${ }^{34}$.

Otro tipo de proyectos fragmentaba los encargos individualizando su ejecución a diferentes maestros. Este es el caso del claustro de la catedral de Toledo, donde se documenta, por ejemplo, la participación de Becerra, contratado para la realización de la pintura al fresco de uno de los lunetos ${ }^{35}$, al lado de otros artistas que van completando todo el programa.

En Valbuena parece que la unidad de taller es un hecho en todo lo que se refiere a los lunetos conservados, lo que no es óbice para advertir ciertos matices diferenciadores que no son más que la expresión de esa participación agrupada, como apuntamos en el caso de la Lactación. Algo similar ocurre con la decoración utilizando grutescos en las bóvedas. Hay para todo una respuesta a un programa unitario y coetáneo, con las señaladas reformas dieciochescas correspondientes a una renovación general del conjunto.

Esa línea del colosalismo miguelangelesco está presente en la concepción de las figuras, en la composición y en la resolución final de las escenas. El concepto decorativo de los enmarcamientos y de los motivos ornamentales que decoran el espacio es fruto de la introducción de esos esquemas a través de la presencia en Italia de artistas españoles, impregnados de esa concepción y vehículos permanentes de novedades, como sucede con Gaspar Becerra o con los artistas genoveses que terminan por asentarse en nuestro país especializados en la pintura mural.

Comentamos como es en la decoración de los palacios de Felipe II donde se dan cita esta serie de innovadores del gusto, que aportan una nueva lectura a la decoración de los espacios interiores en las últimas décadas del siglo xvi. Hemos querido reparar en el hoy ruinoso palacio de Valsaín, en Segovia, objeto también de atenciones ornamentales por parte del monarca y donde se constata la presencia del florentino Rabuyate en torno a los años 1557-58, en la decoración al fresco de las paredes de la capilla, trabajando en unión de otro italiano, Francisco de Matía del

33 En las obras reales es clara la función de Becerra como Maestro con facultad para contratar oficiales que llevaran a cabo el trabajo, según se deduce de la documentación referente a la decoración del palacio del Pardo o en el propio nombramiento del artista como pintor del rey. J. J. Martín González, «El palacio de El Pardo en el siglo XVI», BSAA, t. XXXVI, Valladolid, 1970, págs. 18 y ss. Respecto al uso de cartones preparatorios por Becerra, sobre los que trabajarían sus oficiales, existe el testimonio de Ceán "Los hacía también en cartones del tamaño de las obras que habia de pintar, como lo acostumbraban hacer los grandes profesores de Italia: loable sistema poco usado entre los nuestros, y a lo que se puede atribuir la decadencia del diseño en los siguientes siglos, Juán Agustín Ceán Bermúdez, Diccionario histórico de los más ilustres profesores..., Madrid, 1800, t. I, págs. 107 y ss.

34 Mario di Giampaolo (Coord.), Los frescos italianos del Escorial, Madrid, 1994. En los diferentes trabajos que se agrupan en el texto se intentan sistematizar las intervenciones en la decoración mural del Monasterio.

35 La noticia de la participación de Becerra en la pintura del claustro catedralicio de Toledo es señalada por Ch. R. Post: op. cit., pág. 155. El dato documental es aportado por Manuel R. Zarco del Valle: Documentos de la catedral de Toledo. Datos documentales para la Historia del Arte español, Madrid, 1916, t. II, págs. 138-141. El dibujo preparatorio parece que se trataría del procedente de la Colección Boix y que se reseña en la recopilación de Diego Angulo Iñiguez y Alfonso E. Pérez Sánchez, A Corpus of Spanish Drawings, 1400 to 1600, t. I, Madrid, 1975, núm. 27. 
Buyno. En el pleito sostenido por la pintura del retablo de la capilla de los Alderete entre Rabuyate y el escultor astorgano, colaborador de Becerra, Bartolomé Hernández, los testigos de la parte del florentino no dejan de mencionar las obras realizadas por éste en Valsaín su Magestad le a cometido las obras de la capilla mayor del bosque de segovia e otras muchas pinturas de su magestad... resaltando la importancia de su arte que mereció un encargo regio ${ }^{36}$.

El pleito de los Alderete tiene lugar entre los años 1581-82 y no está de más recordar los datos que Checa ha aportado recientemente a la decoración del palacio segoviano de Valsaín señalando la presencia activa de Becerra y su equipo genovés, junto al resto de los pintores italianos, en los últimos años de la década de los sesenta y comienzos de los setenta ${ }^{37}$. Rabuyate ha trabajado por lo tanto en ambientes cortesanos y en el entorno de los artistas que introducían las novedades en lo que se refiere a la decoración mural. A su formación italiana y a unos contactos que debieron ser frecuentes con su patria, según se desprende de los datos aportados por su testamento, uniría el contacto directo con los nuevos parámetros del gusto amparados bajo la protección real.

La figura de Becerra, apasionante pero todavía bastante escurridiza, hubo de jugar un papel clave. Escultor y pintor real, su obra aparece repetidamente citada en los testimonios de los artistas contemporáneos y de los tratadistas. A él se atribuye en buena parte la entrada en España de la renovación estética miguelangelesca ${ }^{38}$. En Roma trabaja como fresquista a las órdenes de Vasari y Volterra dentro de lo que la profesora María Calí denomina la escuela de Trinita dei Monti, que en sucesivas aportaciones tanto influirá en la implantación del nuevo gusto en España a través del Escorial ${ }^{39}$.

En 1556 se casará en Roma con Paula Velázquez, natural de Tordesillas, para regresar pronto a España. En Valladolid residía en el año 58, donde firma el contrato para la ejecución del retablo mayor de la catedral de Astorga como vecino de la villa. Valladolid ha sido el más fulgurante centro artístico de Castilla y lugar habitual de residencia de la Corte hasta que ésta se fije en Madrid en 1559. Becerra tiene que tener contacto con los italianos que trabajan en Valladolid y sin duda su pericia y sus aportaciones novedosas, de las que se hacen eco los propios encargos reales que pronto llevará a cabo, será celebrada y seguida en los ambientes de la época. La huella de su arte pensamos que es una realidad en los muros del claustro de Valbuena.

Atribuir el conjunto de pinturas murales a los pinceles del enigmático Rabuyate y su taller, tras recibir las aportaciones romanistas de Becerra, entra dentro de lo posible. De este modo en la ejecución del tema, hoy tan perdido, de Jesús ante Pilatos, es indudable la atribución a Gaspar de Palencia, después de una detenida comparación con sus trabajos pictóricos en el retablo de Santa Marta de Astorga (Fig. 10), con un idéntico tratamiento anatómico, manteniendo los convencionalismos en el plegado que habitualmente utiliza ${ }^{40}$. No podemos olvidar la estrecha relación de Palencia con la obra escultórica de Becerra en Astorga. Junto al pintor de Cuenca de Campos, Gaspar de Hoyos, será el policromador del retablo catedralicio, el más claro heraldo de la importación del nuevo gusto en nuestro país, sin duda por recomendación del propio escultor.

36 M. Angeles Martín González, El Real Sitio de Valsaín, Madrid, 1992, pág. 92. La autora documenta la presencia de Rabuyate pintando la capilla del palacio. Martí y Monsó: op. cit, pág. 429 y ss., recoge los testimonios de los testigos en el pleito por la capilla de los Alderete.

37 Fernando Checa Cremades: Felipe II mecenas de las artes, Madrid, 1992, págs. 61-64.

38 Juan José Martín González, "Precisiones sobre Gaspar Becerra», AEA, Madrid, 1969, núm. 168, t. XLII, págs. 327-356.

39 María Calí, De Miguel Angel a El Escorial. Momentos del debate religioso en el arte del siglo XVI, Madrid, 1994, págs. 227 y ss.

40 Sobre el pintor pueden verse dos trabajos de Miguel Angel González García y Manuel Arias Martínez, "A propósito de Gaspar de Palencia», Anuario del Museo de Bellas Artes de Bilbao 1993, Bilbao, 1994 y "Los retablos mayores de la iglesia de Santa Marta de Astorga” en Astórica núm. 14, Astorga, 1995. 
Pero entre todas las composiciones del claustro una en especial destaca por su adscripción a los nuevos vientos que soplaban desde Italia. En el luneto de la Resurrección es obvio que el colosalismo de su tratamiento, en la figura ascendente de Cristo, rompe con la tradición anterior y se pone en la órbita del más puro influjo miguelangelesco. Su corporeidad debe relacionarse con el derroche anatómico que surgió de las formas de la Sixtina, rápidamente difundidas por los artistas fuera de Italia, o con representaciones como la de Perseo en las bóvedas del Pardo. Al mismo Becerra se atribuye el fragmento de un dibujo con el tema del Juicio Final ${ }^{41}$ y es Rabuyate quien cita en su codicilo un lienzo del Juicio entre sus pertenencias, altamente estimado por lo que deja ver su valoración económica, que no ha de ser otro que una buena copia de Miguel Angel ${ }^{42}$. La calidad del fresco, a pesar del abandono de su estado de conservación es muy buena y en su factura debe estar presente la mano de un conocedor de la obra de Buonarroti.

En Valladolid se pueden detectar otras presencias de esta secuela que aún están por medir. El retablo de la Resurrección que, procedente de la capilla de la Real Chancillería, se expone en las salas del Museo Nacional de Escultura presenta un esquema similar en lo compositivo con el fresco de Valbuena aunque el tratamiento lumínico sea más delicado (Figs. 12 y 13).

El retablo, salvo una atribución de Wattenberg a Rabuyate, ha sido siempre, siguiendo a Post, atribuido a Becerra, ayudado por uno de los pintores vallisoletanos que cita en su testamento, Jerónimo Vázquez. Algunos detalles unen las representaciones de Valbuena y Valladolid. Los tritones dispuestos bajo las dos tablas laterales aparecen en los ángulos de los lunetos de Valbuena ${ }^{43}$. Lo mismo sucede con esa original forma del sepulcro flanqueado por volutas como proyección de un capitel jónico que no es nada habitual. En Florencia, Salviati, uno de los pintores de quien poseía Rabuyate copias en su testamento, diseña un cartón de tapiz con esa misma forma de sepulcro.

Es diferente el concepto de la figura principal. La finura del tratamiento anatómico y lumínico del retablo de la Chancillería contrasta con la fortaleza del Resucitado de Valbuena. ¿Hablamos de un mismo autor y de fases distintas de su evolución, o estamos ante maestros y concepciones diferentes? Post consideró la atribución a Becerra del retablo del Museo Nacional de Escultura por pensar que ningún otro pintor del momento podía haber realizado tal obra en Valladolid. Lo conocido de artistas contemporáneos, como Jerónimo Vázquez, deslindada su obra de la de Gaspar de Palencia, no deja lugar a demasiadas opciones. A Gaspar de Palencia hemos creído justo atribuir la tabla de la Aparición de Cristo resucitado a su Madre, hoy en el Museo de los Caminos de Astorga, que sigue fielmente el modelo del retablo de la Chancillería pero con torpeza de copista, sin que nos atrevamos a considerarlo el autor de la cabeza de serie.

Esa falta de corporeidad en la concepción de las figuras del retablo de la Chancillería nos hace recelar de esa histórica atribución a Becerra, únicamente por el mero análisis comparativo con los dibujos preparatorios y las pinturas que con certeza salieron de su taller.

Existen además otros ejemplos para ayudar a evaluar una posible hipótesis, que deben ser

41 Diego Angulo Iñiguez y Alfonso Pérez Sánchez: op. cit., pág. 22, núm. 28, 29.

42 AHP de Valladolid, Protocolos de Tomás López, Legajo 756, fol. 1060 v. A diferencia de los bajos precios que se constatan en todos los bienes expresados en el Codicilo, en esta ocasión el lienzo se valora en doscientos ducados.

43 De esta relación hemos hablado en el trabajo referido a Palencia citado en la nota 40, donde se resume la bibliografía sobre el retablo de la Resurrección y su atribución a Becerra. En cuanto a los tritones debemos mencionar los que se disponen en los aletones del ático del retablo de Juan de Juni en la capilla de los Alderete, como un motivo recurrente en el vocabulario ornamental. 


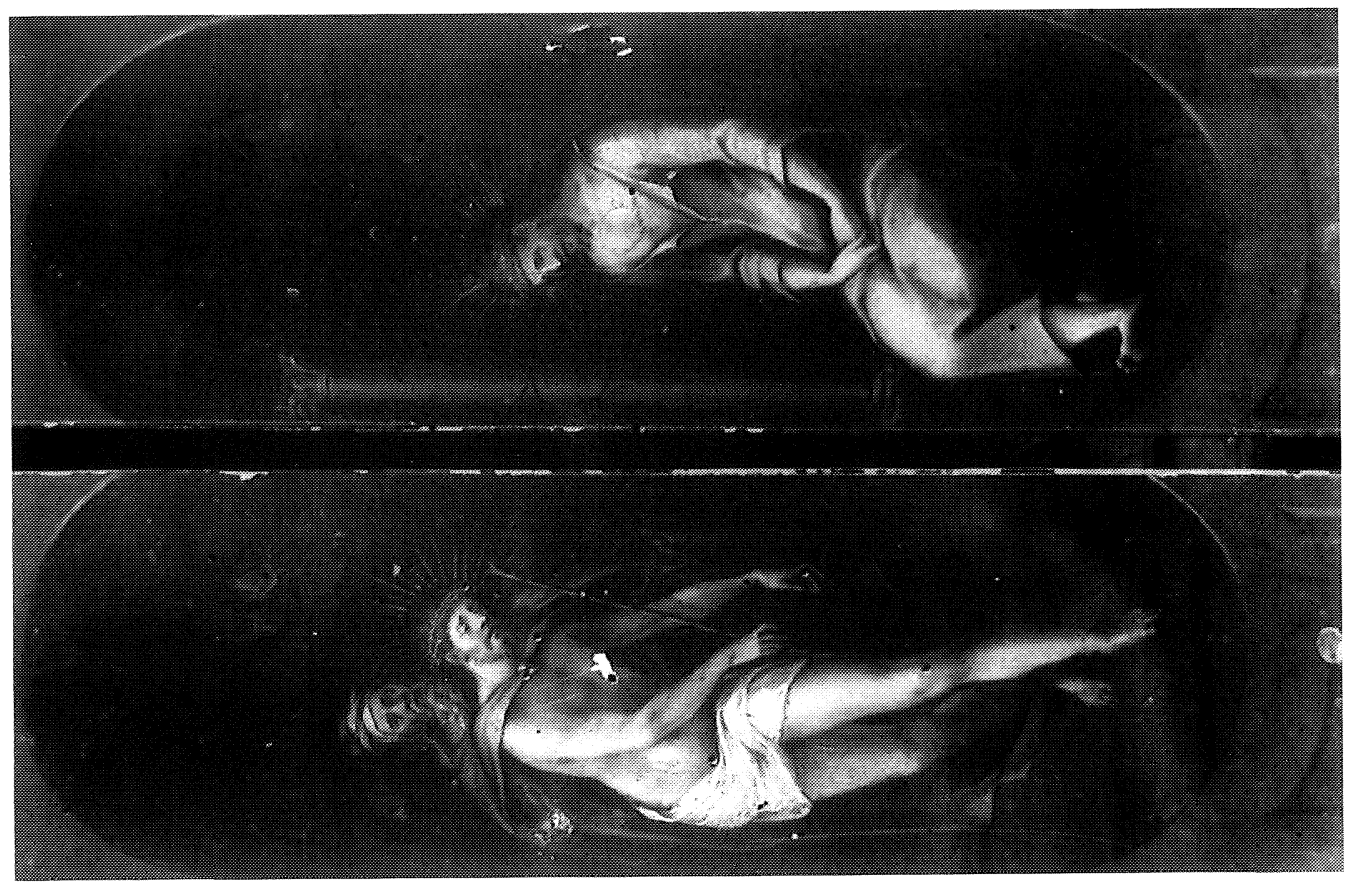

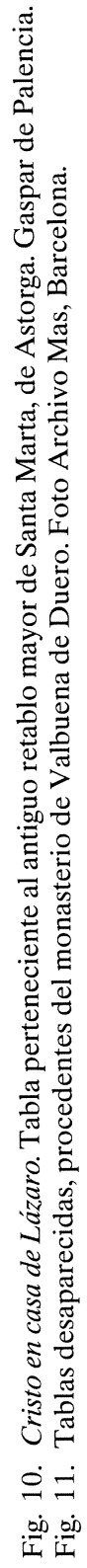

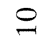 $\exists$

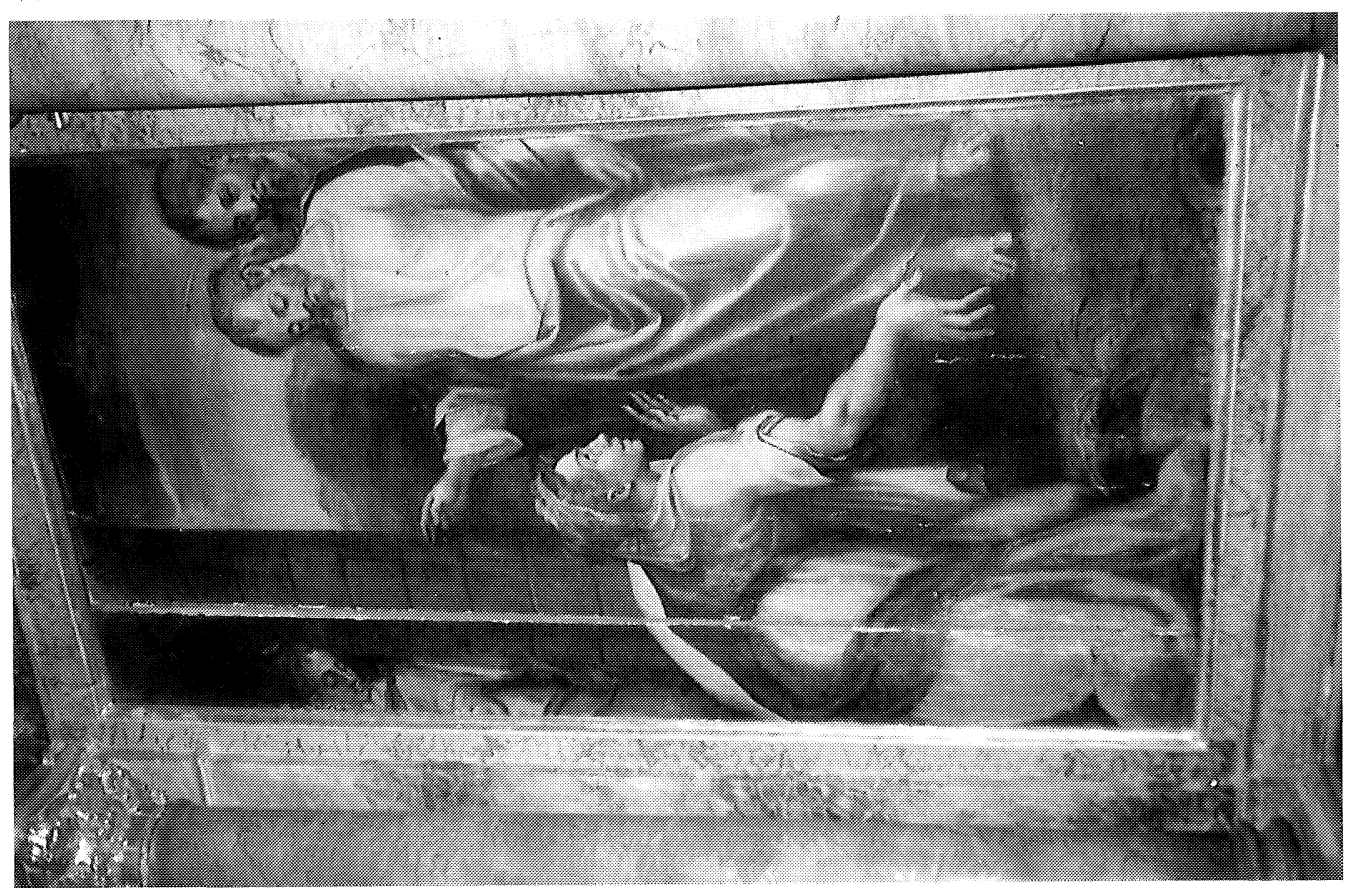



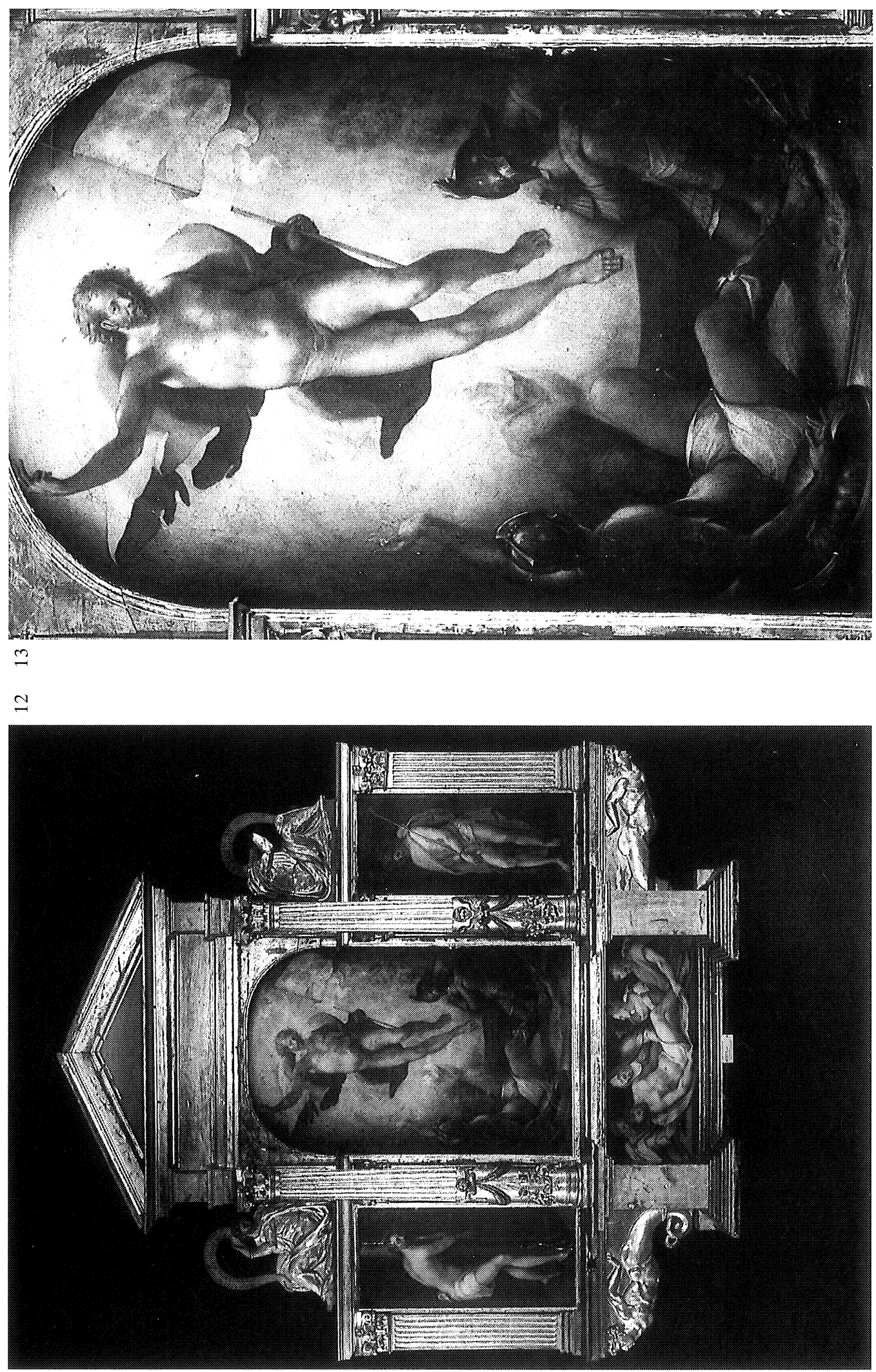

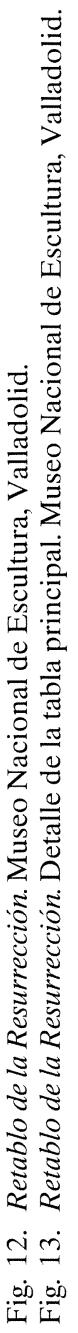


tenidos en cuenta. Del mismo monasterio de Valbuena procedían dos tablas ${ }^{44}$, hoy en paradero desconocido que, por fortuna, fueron fotografiadas para el Archivo Mas de Barcelona y dadas a conocer por Post (Fig. 11). Ambas formaban parte de una misma pieza, probablemente un sagrario, representando dos escenas de la Pasión: Cristo después de la flagelación y el Ecce Homo. La relación con la pintura del retablo de la Chancillería es evidente e idéntica la mano del pintor que lo llevó a cabo, por lo que podemos tener más elementos de juicio. La obra conocida de Becerra no permite afirmar que las tablas de Valbuena le pertenezcan al igual que el retablo de la Chancillería. La calidad de su tratamiento conduce hacia la personalidad del pintor más notable que residió en Valladolid durante la segunda mitad del siglo xvi. Bien pudo ser Rabuyate y su taller quienes emprendieran la tarea decorativa del claustro de Valbuena, sin olvidar la presencia de otras intervenciones con Becerra a la cabeza que incorporaran las novedades italianas.

${ }^{44}$ Ch. R. Post: op. cit., págs. 122-129, las atribuye al pintor afincado en Medina del Campo y muy documentado por García Chico, llamado Antón Pérez. Posteriormente, Diego Angulo Iñiguez, «Pintura española del siglo xvi» en Ars Hispaniae, Madrid, 1954, pág. 195, y Jesús M. ${ }^{a}$ Caamaño, «Tendencias manieristas en la pintura vallisoletana en la segunda mitad del siglo xvin, BSAA, Valladolid, 1962, pág. 19, las atribuirán a Jerónimo Vázquez. Lo que se conoce documentado de ambos pintores no permite mantener esta autoría. 